\title{
アイスクリーム少量製造技術の開発打よび粘度， 温度変化の可視化
}

\author{
佐合 徹 ${ }^{\dagger}$, 山㠃栄次 \\ 三重県工業研究所
}

\section{Preparation of Ice Cream in Small Quantities and Measurement of Physical Changes during the Freezing Process}

\author{
Toru $\mathrm{SAGO}^{\dagger}$, Eiji YAMAZAKI \\ Mie Prefecture Industrial Research Institute, 5-5-45 Takajaya, Tsu, Mie 514-0819, Japan
}

\begin{abstract}
The purpose of this study is to prepare ice cream and sorbet in small quantities and to measure the physical changes that take place during the freezing process using a starch pasting device. Ice cream and sorbet were prepared with $25 \mathrm{~g}$ of the mix using a starch pasting device rotating at 15 revolutions per second and a cooling rate of $1^{\circ} \mathrm{C} / \mathrm{min}$. The flavor of the ice cream and sorbet were almost the same as those prepared with a batch freezer. The increased rotation rate of the ice cream mix reduced the rate of increase in viscosity beyond the freezing point and elevated the levels of overrun after making the ice cream. As the cooling rate of the mix increased, the increase in the viscosity was found beyond the freezing point and the overruns increased after making the ice cream. The application of a starch pasting device allows numerical values to be ascribed to the changes taking place during the production of ice cream and sorbet. In conclusion, small scale production methods can contribute to reducing a large amount of waste generated during trial production and indeed facilitate the trial production of new ice cream products.
\end{abstract}

Keywords: ice cream, sorbet, physical changes, overrun

1. 緒言

アイスクリームは，調合・殺菌した液体状のアイス クリームミックスを擋找し, 凍結（フリージング）させ， 硬化した食品であり，主に，水結晶，脂肪打よび空気 の 3 成分から構成される [1]. H. D. Goff らによると, アイスクリームのフリージング工程に打ける変化は次 の通りである [2]．まず，フリージングによりミックス 中に氷核が発生し，それと同時にミックスが増粘され る。発生した氷核が装置の壁面にて成長するが，スク レーパーによる掻き取りと摚找によって氷の結晶サイ ズや形が適当な範囲で整う。また同時に, 脂肪球の破壞, 凝集が促進されるとともに，擋找によって取り込まれ た空気を安定的に包接されるといわれている.

アイスクリームの品質評価は, 通常原料ミックスと 製品アイスクリームに分けて行わ机ている. ミックス

(受付 2015 年 6 月 30 日, 受理 2015 年 11 月 1 日)

厂 514-0819 三重県津市高茶屋 5-5-45

Fax: +81-59-234-3982, E-mail: sagout00@pref.mie.jp
に関しては，均質化条件設定のための脂肪球粒径測定， 各種物性改良添加物の効果を見積もるための粘度測定, 打よび色調を確認するための測色測定等 [1]が行われて いる. 製品のアイスクリームに関しては, 脂肪球の破壊・ 凝集状態確認のための粒径測定 [3]，さじと打り [4,5] や硬さ [6] を測るためのレオメータといった機器を用い た物性測定, 食感・舌触りに影響を及ぼす水結晶の観 察 [8,9], 溶けやすさを確認するための融解性測定 $[10,11]$ ，官能評価 $[12,13]$ 打よびアイスクリームの食感 に重要な影響を及ぼす空気含有量測定（オーバーラン 測定）[14] などが行われている.

一方，アイスクリームの試作検討には，少なくとも 2 つの課題がある. 1つ目の課題は，試作の規模に関する ことである.フリージング工程において小型のフリー ザを使用した場合でも数 $\mathrm{kg}$ 以上の原料を必要とし, 商 品開発の過程で大量の廃棄物が発生してしまう. 2 つ目 の課題は，フリージング工程における物性変化がよく わかっていないことである。 アイスクリームのフリー ジング装置（バッチフリーザ抢よび連続式フリーザ） が密閉系であるといった構造上の問題と，ミックスか 
らアイスクリームへの変化は温度に関して極めて不安 定であるため，一時的に装置を止めたとしてもアイス クリームの状態を正確に評価することは困難である. したがって，評価対象は前述の通り原料のミックスと 製造された製品に限られる。

本研究では，一般的なバッチフリーザによる場合と 比較し約 $1 / 100$ の少量でのアイスクリームを製造する 技術の開発と，フリージング工程の物性変化の可視化 を目的とした。試料には，国内で乳成分の量によって 4 つに分けられるアイスクリーム類のうち，代表的な配 合のアイスクリームと，そのアイスクリームと大きく 配合が異なる氷菓のミックスを用いた。

\section{2. 実験}

\section{1 アイスクリームおよび氷菓の配合}

アイスクリームミックスは，市販品（無脂乳固形分 $6.0 \%$, 植物性脂肪分 $6.0 \%$, 日世）を使用した。水菓（食 品衛生法にもとづく厚生省告示「食品，添加物等の規 格基準」により定義された乳固形分 $3.0 \%$ 未満のものを 示す.）のミックスは，オレンジ・うんしゅうみかん混 合果汁 (商品名: POM ポンジュース，えひめ飲料) $70 \%$ ，水あめ（商品名：水飴，三重化糧） $30 \%$ の基準 品と，基準品にペクチン（商品名：共立ペクチン，共 立食品） $1.0 \%$ 添加（w/w）したものを混合し， $75^{\circ} \mathrm{C}$, 10 分の殺菌後，水水にて冷却したものの 2 種類を使用 した.

\section{2 アイスクリームおよび氷菓の製造条件}

アイスクリームと水菓は, 動的粘弾性測定装置 (ARG2，TA Instruments）におけるデンプンの糊化特性評 価システム（Starch pasting cell）（Fig. 1）により，約 $10^{\circ} \mathrm{C}$ のミックス $25 \mathrm{~g}$ をアルミ製円柱状容器（内径 37

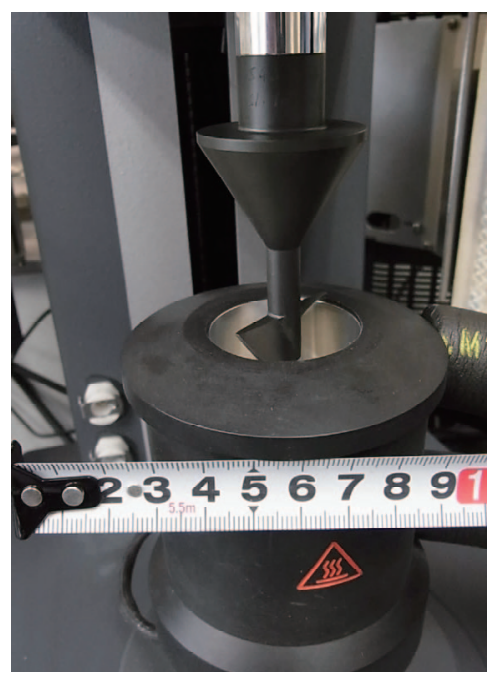

Fig.1 Photograph of a Starch pasting cell. $\mathrm{mm}$, 高さ $64 \mathrm{~mm}$ ) に入れ，擋拌治具と容器のギャッ

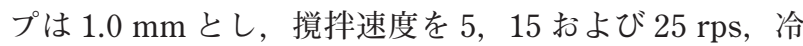
却速度を $0.8,1.0$ 打よび $1.6^{\circ} \mathrm{C} / \mathrm{min}$ と制御してフリー ジングを行った。 また，アイスクリームと氷菓の官能 評価を見た目の色の濃さ，ざらつき，後味の 3 項目に ついて，7段階評点にて専門パネル 4 名で行った。

\section{3 アイスクリームおよび氷菓に含有されるオーバー}

\section{ランの測定}

アイスクリームの空気量（オーバーランという）は, フリージング前の試料であるミックスを容量 $10 \mathrm{~mL}$ の プラスティック製カップに充填し重量を計測しておき (A g)，フリージングを経たアイスクリームあるいは氷 菓を同様に重量計測し（B g)，(1) 式より算出した [15].

$$
\text { オーバーラン }(\%)=(\mathrm{A} / \mathrm{B}-1) \times 100
$$

\section{3. 結果および考察}

\section{1 アイスクリームの少量製造}

擋拌速度を 5 ， 15 および $25 \mathrm{rps}$ とし，冷却速度を一 定 $\left(1.0^{\circ} \mathrm{C} / \mathrm{min}\right)$ とした場合のフリージング工程におけ るアイスクリームミックスの粘度変化，温度変化を Fig. 2 に示す。バッチフリーザに打けるアイスクリーム製造

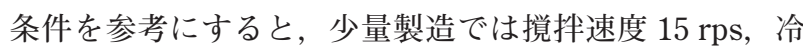
却速度 $1.0^{\circ} \mathrm{C} / \mathrm{min}$ という製造条件と合致する。 そこで, Fig. 2 に打けるその条件での結果に着目した。市販のア イスクリームは，ミックスを冷却して $-3.0^{\circ} \mathrm{C}$ から $-9.0^{\circ} \mathrm{C}$ 付近で水結晶が生成し，粘度上昇とともにオー バーランが増加し，アイスクリームになるといわれて

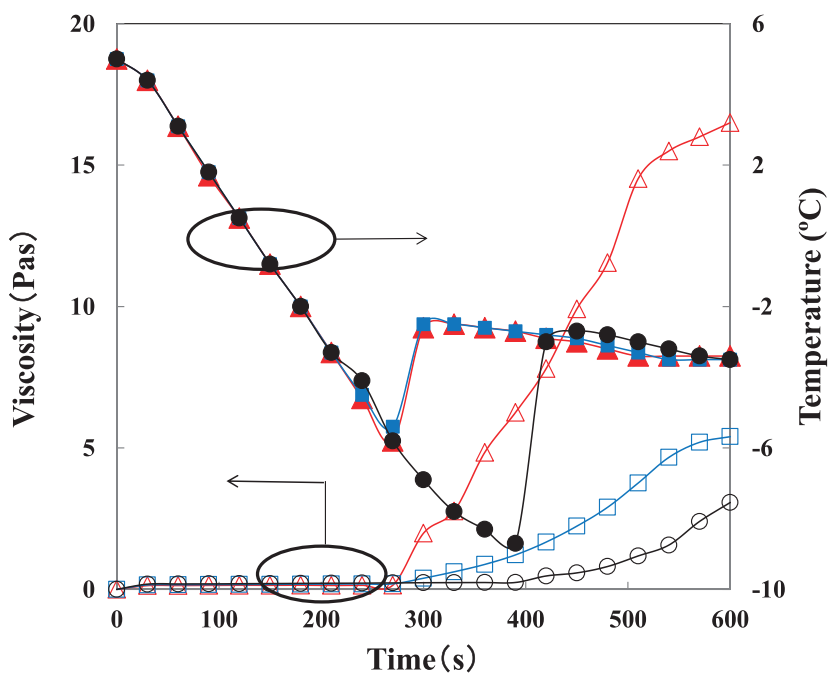

Fig.2 Effect of the rotation rate on the viscosity and the temperature of ice cream mix (cooling rate $1.0^{\circ} \mathrm{C} / \mathrm{min}$ ). Rotation rate at $5 \mathrm{rps}$ : viscosity $(\triangle)$, temperature $(\boldsymbol{\Delta})$, Rotation rate at $15 \mathrm{rps}$ : viscosity $(\square)$, temperature (ם), Rotation rate at $25 \mathrm{rps}$ : viscosity $(\bigcirc)$, temperature $(\bullet)$ 
いる [1,2]. 本研究では, 擋找しながら温度を低下させ たところ，凍結温度となる $-5.4{ }^{\circ} \mathrm{C}$ を境にして温度が $-2.0^{\circ} \mathrm{C}$ まで急上昇するとともに粘度が上昇した (Fig. 2).

温度上昇は, 水の生成による凝固熱の放出に伴うも のと考えられ，氷の生成，成長が引き金となってミッ クスの流動性は低下し, 粘度が上昇したと考えられる. 擋拌により取り込まれた空気は微細化, 均一化されミッ クス内に安定的に残るため，オーバーランの值は上昇 する。アイスクリームは，バッチフリーザあるいは連 続式フリーザにてミックスを擋找しながら冷却してお り，フリーザから取り出すときの温度が製造工程にお いて重要とされている. 市販のアイスクリームのフリー ザ取り出し温度は $-3.0^{\circ} \mathrm{C} \sim-6.0^{\circ} \mathrm{C}[16]$ であることを考 慮し， $-3.5^{\circ} \mathrm{C}$ に達した時点でフリージングを終了した ところ, 粘度が 5.4 Pas で, オーバーランは $19 \%$ を示 した (Table 1). 官能評価の結果，少量製造したアイス クリームの風味と食感はバッチフリーザで製造した場 合とほぼ同等であった。すなわち，重量比で約 $1 / 100$ の少量で製造したアイスクリームとバッチフリーザで 製造したアイスクリームの品質は同等であったことを確 認した。 また，今回のフリージングは 600 秒程度で完了 した。バッチフリーザおよび連続式フリーザによる実生 産時のフリージング時間は 600 秒程度で行われているこ とから, 少量での冷却速度は実生産時の冷却速度とほぼ 一致していた。 そこで，以降のフリージングは，600 秒 間で行うこととした.

本研究による手法は，バッチフリーザなどと比較し て極端に少量の製造が達成できるが，官能評価におい て十分な試料量を確保することが困難であるといった デメリットがある。しかしながら，アイスクリームの 新商品開発過程にて発生する廃棄物を大幅に減らすこ とが可能である。さらに，フリージング工程の物性変 化を粘度と温度により可視化することにより，試作お よび製造現場にて熟練作業者の経験に委ねられてきた 作業を客観的に評価ができるようになることで，数值 によって作業者全員が共通の指針をもって理解するこ とができる。それにより，経験だけでない次世代のも のづくり技術の継承に大いに役立つこと, 製造中のト ラブルへの対処が迅速にできるようになり，生産性が 安定することが期待できる.

Table 1 Overruns after freezing the ice cream mix.

\begin{tabular}{ccc}
\hline Rotation rate (rps) & Cooling rate $\left({ }^{\circ} \mathrm{C} / \mathrm{min}\right)$ & Ove rrun $(\%)$ \\
\hline 5 & 1.0 & 8.3 \\
15 & 1.0 & 19.0 \\
25 & 1.0 & 37.0 \\
\hline 15 & 0.8 & 12.4 \\
15 & 1.6 & 30.6 \\
\hline
\end{tabular}

3.2 撹拌速度がアイスクリームのフリージングエ程の 粘度変化, 温度変化およびオーバーランに与える影響

3.1 でアイスクリームの少量製造が可能となった。こ の方法を用いて，冷却速度を一定にして，擋拌速度が フリージング工程の粘度変化, 温度変化扎よびオーバー ランに及ぼす影響を調べた。

擋找速度を $5,15 \mathrm{rps}$ とした時と比べて擋拌速度を 25 $\mathrm{rps}$ に上昇すると, 凍結温度が約 $3.0^{\circ} \mathrm{C}$ 下がり, $-8.7^{\circ} \mathrm{C}$ となった（Fig. 2)，激しく擋找されることにより，凍 結により生じた氷核の成長よりも，再融解が優先とな り, 凍結温度が低下したと考えられる. H. D. Goff ら [2] は，ミックスを冷却していくことで凍結する温度であ る凍結点をショ糖濃度を基準とし算出する方法や測定 する方法を紹介している. しかしながら, 彼らの手法は, 静置状態で導出され，擋找が考慮されていない，本研 究手法でモニタリングし測定した凍結温度は，実際の 擋拌と同様の工程により得られた值であり，真の凍結 温度と推定される.

擋拌速度が上昇すると，凍結温度を超えた後の粘度 上昇の傾きが緩やかになり，擋找速度 $5 \mathrm{rps}$ および 25 rps の時は，それぞれ 600 秒後の粘度が 16 Pas および 3.1 Pas となった.この結果は, S. Kokubo ら [17]による 連続式フリーザでの結果と類似するものであった。 S. Kokubo ら [17] は摚拌速度が上昇すると, 脂肪球の凝 集が促進されることにより，粘度はやや低い範囲にと どまるものの保形性が改善されると考えている.アイ スクリームの保形性が向上すると，食べやすい物性を 保持したまま外観上溶けにくくなる.アイスクリーム が溶けにくくなったことで，消費者はアイスクリーム をより長い時間楽しむことができる. 本研究の手法は, 保形性の評価に活用できると考えられ，アイスクリー ムの品質改良にも貢献できる可能性がある。

擋拌速度を $5 \mathrm{rps}$ から $25 \mathrm{rps}$ に増加させると，オー バーランは $8.3 \%$ から $37 \%$ に増加した (Table 1). 擋拌 により空気の取り込みの増加と, 脂肪凝集による気泡 の安定が並行して進行したため，オーバーランが増加 したと考えられる。今回の条件では，擋找が早いほど オーバーランは増加したが, 擋找速度をさらに増加さ せた場合，脂肪凝集が進みすぎることによるチャーニ ング (バターのような状態になる) の発生が考えられる. 今後, 摚拌速度とチャーニング現象との関係を検討し ていきたい.

\section{3 冷却速度がアイスクリームのフリージングエ程の} 粘度変化, 温度変化およびオーバーランに与える影響

摚拌速度を一定にして, 冷却速度 $0.8,1.0$ および $1.6^{\circ} \mathrm{C}$ /min とした場合のフリージング工程での粘度変化, 温 度変化を Fig. 3 に，フリージング後のアイスクリーム のオーバーランを Table 1 に示す. 


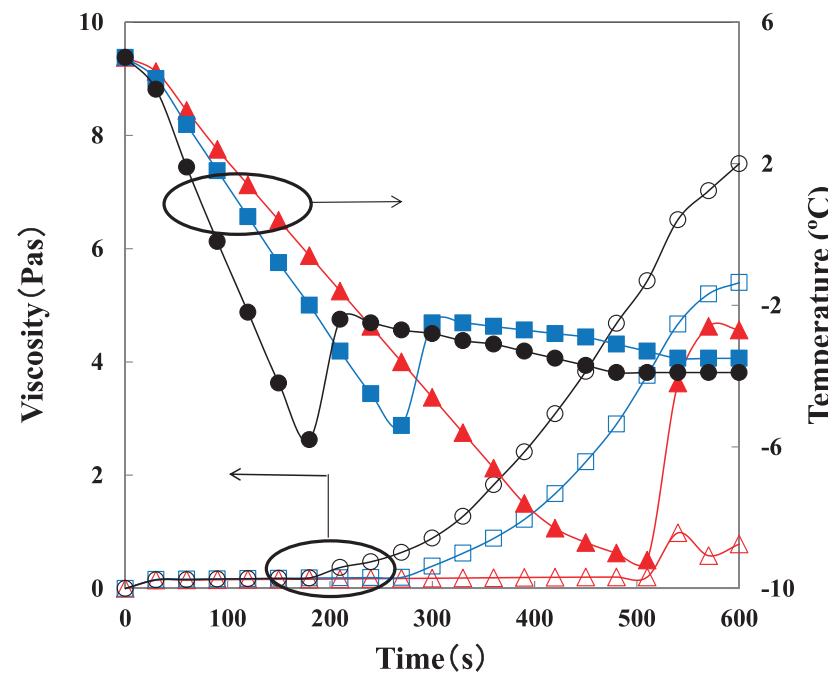

Fig.3 Effect of cooling rate on the viscosity and temperature of ice cream mix (rotation rate $15 \mathrm{rps}$ ).

Cooling rate at $0.8^{\circ} \mathrm{C} / \mathrm{min}$ : viscosity $(\triangle)$, temperature $(\mathbf{A})$, Cooling rate at $1.0^{\circ} \mathrm{C} / \mathrm{min}$ : viscosity $(\square)$, temperature $(\mathbf{\square})$, Cooling rate at $1.6^{\circ} \mathrm{C} / \mathrm{min}$ : viscosity $(\bigcirc)$, temperature $(\bullet)$.

冷却速度を 1.0 抢よび $1.6^{\circ} \mathrm{C} / \mathrm{min}$ とした時, 凍結温度 が $0.8^{\circ} \mathrm{C} / \mathrm{min}$ に比べて約 $3.0^{\circ} \mathrm{C}$ 上昇し， $-6.0^{\circ} \mathrm{C}$ となった (Fig. 3)。冷却速度の増加は, 水核の発生と成長を促進 させるため，凍結温度が上昇したと考えられる，粘度 に関しては，冷却速度が $0.8^{\circ} \mathrm{C} / \mathrm{min}$ から $1.6^{\circ} \mathrm{C} / \mathrm{min} に$ 増加すると， 600 秒後の粘度は 0.8 Pas から 7.0 Pasに 上昇した。同様に，オーバーランも，冷却速度が $0.8^{\circ} \mathrm{C}$

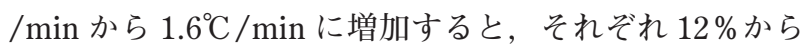
$31 \%$ に増加した，冷却速度が増加すると，水核の生成 と成長が促され，アイスクリームの組織の中で，固体 である水の占める割合が大きくなり, 粘度上昇の程度 が急になったと考えられる。ささらに, 粘度の上昇により, 取り込まれた空気は移動しにくくなることから，オー バーランは増加したと考えられる。 今回の条件では, 冷却速度を上げるほどオーバーランは増加したが，さ らに, 冷却速度を増加した場合, フリージングに必要 なもう 1 つの要素である擋拌が追い付かず，十分な食 感をもったアイスクリームにならない可能性も考えら れる，今後，アイスクリームの食感に対する冷却速度 と擋拌速度の相関性を検討していく必要がある.

本研究に打いて擋找速度打よび冷却速度を制御しつ つ，フリージング工程の温度と粘度を測定することに より，フリージング工程の凍結温度や粘度変化が，オー バーランに密接に関係していることを明らかにした。 つまり，温度や粘度を制御することにより，オーバー ランを自在に調整できる可能性を実証したものと考え られる。オーバーランは，アイスクリームのやわらか さやなめらかさといった食感に影響を及ぼすだけでな く，歩留りに直結することから，アイスクリーム製造
での最も重要な管理指標の 1 つである. 本研究の少量 製造でのオーバーランを調整することで，新商品の開 発設計や生産性の向上に貢献できる.

\section{4 少量での永菓の製造, フリージングエ程の物性} 変化

アイスクリームとは大きく配合が異なる氷菓に本研 究の少量製造技術の適用を試みた。ペクチン添加量を $0 \%$ 打よび $1 \%$ とし，擋拌速度と冷却速度を一定（15 $\mathrm{rps} ， 1^{\circ} \mathrm{C} / \mathrm{min}$ ) とした場合のフリージング工程に打け る粘度変化，温度変化を Fig. 4 に示す。一般に，市販 の水菓は，ミックスを冷却して $-3.0^{\circ} \mathrm{C}$ から $-9.0^{\circ} \mathrm{C}$ 付近 で水結晶が生成し，粘度上昇とともにオーバーランが 増加し, 氷菓になる $[1,2]$. 本研究では, 擋拌しながら 冷却したところ，ペクチンを添加しない場合， $-8.7^{\circ} \mathrm{C}$ を境にして温度が $-3.3^{\circ} \mathrm{C}$ まで急上昇するとともに粘度 が上昇した (Fig. 4).

温度上昇は，アイスクリームの場合と同様に氷核の 生成による凝固熱の放出に伴うと考元られ，水核の生 成，成長が引き金となってミックスの流動性は低下し， 粘度が上昇したものと考えられる。アイスクリームと 同様にフリーザから取り出すときの温度が製造工程に 扔いて重要とされている. 市販の水菓のフリーザ取り 出し温度は $-3.0^{\circ} \mathrm{C} \sim-6.0^{\circ} \mathrm{C}[16]$ であることを考慮し， $-6.0^{\circ} \mathrm{C}$ に達した時点でフリージングを終了したところ, 粘度が 2.4 Pasで，オーバーランは $14 \%$ を示した。擋 找により取り込まれた空気は微細化，均一化されミッ クス内に安定的に残るため，オーバーランの值は上昇 したと考えられる。官能評価したところ，風味と食感

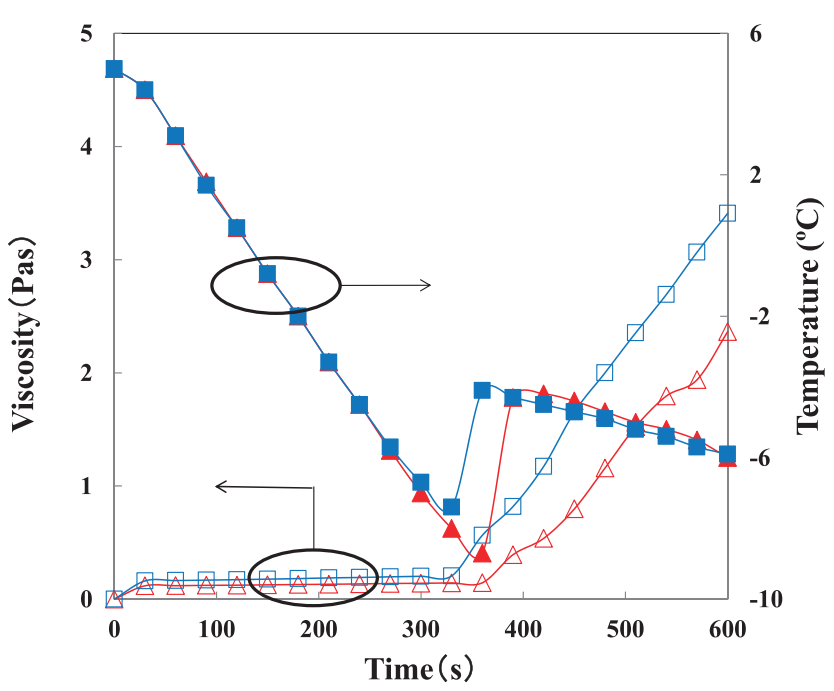

Fig.4 Effect of pectin addition on the viscosity and temperature of sorbet mix at a rotation rate of $15 \mathrm{rps}$ and a cooling rate of $1.0^{\circ} \mathrm{C} / \mathrm{min}$

Without pectin : viscosity $(\triangle)$, temperature $(\boldsymbol{\Delta})$, Containing of $1.0 \%$ pectin : viscosity $(\square)$, temperature (ם). 
がバッチフリーザで製造した場合とほぼ同等であった。 したがって，3.1のアイスクリームと同様に本研究の技 術は氷菓にも適用できることがわかった。

一般的な水菓ミックスは，アイスクリームミックス と比べて水分量が多いため, 水核が発生, 成長しやすく, 生成した氷結晶が大きい。 また，脂肪を含まないため, 前述のアイスクリームのように凝集した脂肪が気泡を 取り囲むことによるオーバーランの増加効果は期待で きない，そのため，氷が直接舌に接するため冷たさが 強調され，またアイスクリームのような気泡によるな めらかさが少ないとされている [1]. 市販の水菓は， ペ クチンなどの増粘安定剤を添加し，水核の発生，成長 を抑制している。ペクチンは増粘安定戍として，水核 の発生，成長を抑制する効果や乳成分を安定化する効 果が知られ，脱脂粉乳といった乳固形分を用いた氷菓 やフローズンヨーグルトに添加されることが多い [1]. そこで，次にペクチンを添加し，その影響を検討した。

冷却速度 $1.0^{\circ} \mathrm{C} / \mathrm{min}$ とし，ペクチンを $1.0 \%$ 添加した 場合, 凍結温度が約 $1.0^{\circ} \mathrm{C}$ 上がり, $-7.4^{\circ} \mathrm{C}$ となった（Fig. 4). 粘度に関しては, ペクチンを $1.0 \%$ 添加すると, 凍 結後の粘度上昇の傾きが急になった. 600 秒後の粘度は, ペクチン無添加打よび $1.0 \%$ 添加の時，それぞれ 2.4 Pas および 3.4 Pas となった. 同様に，オーバーランは それぞれ $14 \%$ および $22 \%$ となった。

フリージング工程に打けるペクチン $1.0 \%$ 添加は，水 核の発生と成長を抑制する効果はほとんどなく，むし ろわずかに促進する可能性があり, 水菓の組織の中で, 固体である水の占める割合が高くなり，粘度上昇の程 度が急になったと考えられる。一方, 粘度の上昇により， 取り込まれた空気は移動しにくくなることから，オー バーランは増加したと考えられる.

本研究に打ける氷菓のミックスでは， $1.0 \%$ のペクチ ン添加では氷核の発生・成長抑制に効果が期待できな かった。水菓は水分量が多いことから，アイスクリー 厶と比較して氷核の生成・成長は早いと考えられる. 水核の生成・成長の抑制を四るためには，ペクチン添 加量の増量や異なる種類の増粘安定剂を利用，あるい は併用することが必要となると考えられる。

\section{4. 結論}

デンプンの糊化特性評価機器を応用して，アイスク リームや水菓を一般的なバッチフリーザと比較して約 $1 / 100$ の少量で製造する技術を確立した。また，従来不 明であったフリージング工程の粘度変化, 温度変化を 連続的にモニタリングすることに成功した。これら開 発技術により, 擋拌速度の増加は, 凍結後の粘度勾配 の緩化，オーバーランを増加させることを明らかにし た。さらに，冷却速度の増加は凍結後の粘度勾配を上
昇させ，オーバーランを増加させることを明らかにし た。なお，本研究による少量製造技術打よびフリージ ング中の物性変化モニタリング技術は氷菓製造にも利 用可能であった。

\section{引用 文 献}

1) S. Yuyama; "Production of Ice Cream", Kourin, Tokyo, Japan, 1996, pp. 216-238.

2) H. D. Goff, R. W. Hartel; “Ice Cream 7 th”, Springer, 2013, p. 313-339.

3) C. M. Velasco, H. D. Goff; Fat structure in ice cream: a study on the types of fat interactions. Food Hyd., 29, 152-159 (2012).

4) S. Bolliger, H. Wildmoser, H. D. Goff, B. W. Tharp; Relationships between ice cream mix viscoelasticity and ice crystal growth in ice cream. Int. Dairy J., 10, 791-797 (2000).

5) B. Elhweg, I. W. Burns, A. B. Russell. D. I. Wilson; Viscous dissipation and apparent wall slip in capillary rheometry of ice cream. Food Biopro. Pro., 87, 266-272 (2009).

6) A. M. Roland, L. G. Phillips, K. J. Boor; Physical characteristics of frozen desserts made with cream, anhydrous milk fat or milk fat fractions. J. Dairy Sci., 82, 2094-2100 (1999).

7) A. M. Rahman, S. A. Madkor, F. S. Ibrahim, A. Kilara; Effects of fat replacers on the sensory properties, color, melting, and hardness of ice cream. J. Dairy Sci., 80, 1926-1935 (1997).

8) A. A. Flores, H. D. Goff; Ice crystal size distributions in dynamically frozen model solutions and ice cream as affected by stabilizers. J. Dairy Sci., 82, 1399-1407 (1999).

9) T. Hagiwara, R. W. Hartel; Effect of sweetener, stabilizer, and storage temperature on ice recrystallization in ice cream. J. Dairy Sci., 79, 735-744 (1996).

10) M. M. Koxholt, B. Eisenmann, J. Hinlichst; Effect of the Fat Globule Sizes on the Meltdown of Ice Cream. J. Dairy Sci., 84, 31-37 (2001).

11) M. R. Muse, R. W. Hartel; Ice cream structural elements that affect melting rate and hardness. J. Dairy Sci., 87, 1-10 (2004).

12) D. B. Aime, S. D. Arntfield, L. J. Malcolmson, D. Ryland; Textural analysis of fat reduced vanilla ice cream products. Food Res. Int., 34, 237-246 (2001).

13) T. Toyoda, M. Mayanagi; "A factor analysis model for an experiment having repeated measures -a sensory evaluation of ice cream-" (in Japanese). J. Behav. Soc. Japan., 28, 1-7 (2001).

14) Y. Chang, R. W. Hartel; Development of air cells in a batch ice cream freezer. J. Food Eng., 55, 71-78 (2002).

15) K. Yamauchi, K. Yokoyama; "Milk Sougou Jiten", Asakurashoten, Tokyo, Japan, 1992, pp. 336-337. 
16) K. Inoue; "Control of quality of ice cream with freezing process” (in Japanese). Japan Milk Science, 59, 37-47 (2010).

17) S. Kokubo, K. Sakurai, M. Hattori, M. Tomita; "Effects of dasher type and revolution number of dasher on de-emulsified fat of ice cream” (in Japanese). Japan Nippon Shokuhin Kagaku Kougaku Kaishi, 42, 183-189 (1995).

\section{要 旨}

デンプンの糊化特性評価機器を応用し，アイスクリー ム打よび氷菓の少量製造とフリージング工程の物性変

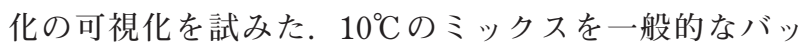
チフリーザ容量の約 1/100（25 g)，擋找速度 $15 \mathrm{rps,}$
冷却速度 $1^{\circ} \mathrm{C} / \mathrm{min}$ で製造を試みたところ $-5.4^{\circ} \mathrm{C}$ で凍結 が確認され，終了時の粘度およびオーバーランは，そ れぞれ 5.4 Pas 打よび $19 \%$ となった。製造されたアイ スクリームの食味は，バッチフリーザで製造されたも のと同等であった。この製造技術は氷菓にも利用可能 であった．擋找速度の増加は, 凍結後の粘度勾配の緩化, オーバーランを増加させることを明らかにした。ささ に, 冷却速度の増加は凍結後の粘度勾配を上昇させ, オーバーランを増加させることを明らかにした，フリー ジング工程の物性変化を数值化できた。本手法は，試 作時の大量の廃棄物を削減できるだけでなく，新商品 開発に貢献するものと期待できる. 